Published in "Deep Sea Research Part II: Topical

Studies in Oceanography 99(): 227-236, 2014"

which should be cited to refer to this work.

\title{
Environmental boundary conditions of cold-water coral mound growth over the last 3 million years in the Porcupine Seabight, Northeast Atlantic
}

\author{
Jacek Raddatz ${ }^{\mathrm{a}, *}$, Andres Rüggeberg ${ }^{\mathrm{a}, \mathrm{b}, \mathrm{c}}$, Volker Liebetrau ${ }^{\mathrm{a}}$, Anneleen Foubert ${ }^{\mathrm{a}, \mathrm{c}, \mathrm{d}}$, \\ Ed C. Hathorne ${ }^{a}$, Jan Fietzke ${ }^{a}$, Anton Eisenhauer ${ }^{a}$, Wolf-Christian Dullo ${ }^{a}$ \\ a GEOMAR Helmholtz-Zentrum für Ozeanforschung Kiel, Wischhofstr. 1-3, 24148 Kiel, Germany \\ ${ }^{\mathrm{b}}$ Renard Centre of Marine Geology, Department of Geology and Soil Sciences, Ghent University, Krijgslaan 281, S8, B-9000 Gent, Belgium \\ ${ }^{\mathrm{c}}$ Department of Geosciences, University of Fribourg, Chemin du Musée 6, CH-1700 Fribourg, Switzerland \\ ${ }^{\mathrm{d}}$ Department of Earth and Environmental Sciences, KU Leuven, Celestijnenlaan 200 E, B-3001 Leuven, Belgium
}

IODP Expedition 307 made it for the first time possible to investigate the entire body of a cold-water coral carbonate mound. Here we provide new insights into the long-term history of Challenger Mound on the European continental margin off Ireland. This study is based on age determinations $\left({ }^{230} \mathrm{Th} / \mathrm{U}\right.$, $\left.{ }^{87} \mathrm{Sr} /{ }^{86} \mathrm{Sr}\right)$ and geochemical signals $(\mathrm{Mg} / \mathrm{Li}$ and $\mathrm{Ba} / \mathrm{Ca})$ measured in the scleractinian cold-water coral Lophelia pertusa from IODP Site 1317 in the Porcupine Seabight. The paleoceanographic reconstructions reveal that coral growth in the Porcupine Seabight was restricted to specific oceanographic conditions such as enhanced export of primary production and Bottom-Water Temperatures (BWT) between $\sim 8$ and $10{ }^{\circ} \mathrm{C}$, related to the water mass stratification of the Mediterranean Outflow Water (MOW) and Eastern North Atlantic Water (ENAW). The geochemical signals from the coral skeletons can be explained by the close interaction between cold-water coral growth, sea-surface productivity and the surrounding water masses - the boundary layer between MOW and ENAW. Enhanced sea-surface productivity and the build-up of a stable water mass stratification between ENAW and MOW caused enhanced nutrient supply at intermediate water depths and facilitated a steady mound growth between $~ 3.0$ and $2.1 \mathrm{Ma}$. With the decrease in sea-surface productivity and related reduced export productivity the food supply was insufficient for rapid coral mound growth between $\sim 1.7$ and $1 \mathrm{Ma}$. During the late Pleistocene (over the last $\sim 0.5 \mathrm{Myr}$ ) mound growth was restricted to interglacial periods. During glacials the water mass boundary between ENAW/MOW probably was below the mound summit and hence food supply was not sufficient for corals to grow.

\section{Introduction}

\subsection{Background}

Cold-water coral carbonate mounds are common features in certain parts of the worlds oceans (Roberts et al., 2006). Over the last 20 years these unique ecosystems have attracted increasing interest in their origin, growth and demise. The environmental boundary conditions necessary for their initiation are still debated. The continental slopes along the European margins contain large provinces of cold-water coral mounds and reefs (Freiwald et al., 2004; Roberts et al., 2006). Here mounds are mainly built by the

\footnotetext{
* Corresponding author.

E-mail address: jraddatz@geomar.de (J. Raddatz).
}

scleractinian cold-water corals Madrepora oculata and Lophelia pertusa. The appearance and distribution of these heterotrophic and filter-feeding corals is controlled by several parameters. Settlement of coral larvae only occurs on hard substrata preferentially on continental slopes, seamounts or oceanic ridges. These areas are often associated with high sea-surface productivity and enhanced current strength (e.g. Guinotte et al., 2006; White et al., 2005). In particular, $L$. pertusa tolerates a wide range of temperatures $\left(4^{\circ}-14^{\circ} \mathrm{C}\right)$ and salinities of $32-39$, but mostly occurs in salinities between 35 and 37. It appears that the seawater density plays an important role in the distribution of living Lophelia-reefs and mounds on the European continental margin. The study of Dullo et al. (2008) highlighted that vivid Lophelia-reefs along the SW Irish and Norwegian margin tend to occur within a narrow density envelope between sigma theta $\left(\sigma_{\theta}\right)=27.35-27.65$ (Dullo et al., 2008). However, this finding appears not to be valid for each 
Lophelia - reef as exceptions can be found for example in submarine canyons in the Bay of Biscay and in the Mediterranean Sea (e.g Freiwald et al., 2009; Huvenne et al., 2011). Living and fossil reefs occur from northern Norway in the Barents Sea $\left(70^{\circ} \mathrm{N}\right.$, Lindberg et al., 2007) to NW Africa off Mauritania $\left(16^{\circ} \mathrm{N}\right.$, Colman et al., 2005). On the Norwegian margin large flourishing reefs developed after the retreat of the glaciers at the end of the last glacial, forming the largest known living cold-water coral reefs in the worlds oceans (Freiwald et al., 2004; Fosså et al., 2005). The margin southwest of Ireland represents a major region of abundant cold-water coral carbonate mounds that tend to cluster in provinces (De Mol et al., 2007; Freiwald et al., 2004) and vary in height from a few metres up to $>380 \mathrm{~m}$ (Wheeler et al., 2007). Especially, the Porcupine Seabight is characterised by different mound provinces some of which contain over 1000 buried and exposed mounds (Huvenne et al., 2007). The Belgica Mound province is one of five mound provinces (De Mol et al., 2002; Foubert et al., 2005; Wheeler et al., 2011) and the Challenger Mound is one of 66 mounds in the Belgica Mound Province. Here, the coral mounds are elongated, subconical structures and occur at depths between 600 and $1000 \mathrm{~m}$, corresponding to the transition zone of Eastern North Atlantic Water (ENAW) and the underlying Mediterranean Outflow Water (MOW) with temperatures of $\sim 9.5^{\circ} \mathrm{C}$ (White, 2007; Fig. 1). Due to the large differences in density between the ambient intermediate water masses a pycnocline forms at around $\sim 800 \mathrm{~m}$ (Dickson and McCave, 1986; Dullo et al., 2008; White and Dorschel, 2010). Here, corals benefit from organic matter that settles from the sea surface through vertical migration. The resuspension of organic matter by internal waves might be one reason for a general steady supply of nutrients into the Porcupine Seabight mound regions (White, 2007; Kiriakoulakis et al., 2007). Purser et al. (2010) demonstrated that L. pertusa polyps capture more efficiently zooplankton under low flow velocities of about $5 \mathrm{~cm} \mathrm{~s}^{-1}$. These specific hydrodynamic conditions facilitate dense cold-water coral growth and mound build up SW of Ireland (De Mol et al., 2002; Kano et al., 2007).

\subsection{Paleoceanographic reconstruction with scleractinian cold-water corals}

Deep-sea or cold-water corals thrive in dark, cold and nutrient rich waters. Similar to their tropical counterparts their skeleton is composed of aragonite and hence can be used as an archive for paleoceanographic reconstructions (e.g. Adkins et al., 1998). Recent developments highlighted the use of $\mathrm{Mg} / \mathrm{Li}(\mathrm{Li} / \mathrm{Mg}$ ) and $\mathrm{Li} / \mathrm{Ca}$ ratios in scleractinian corals as a proxy for temperature (Case et al., 2010; Hathorne et al. 2013). In this study we use the $\mathrm{Mg} / \mathrm{Li}$

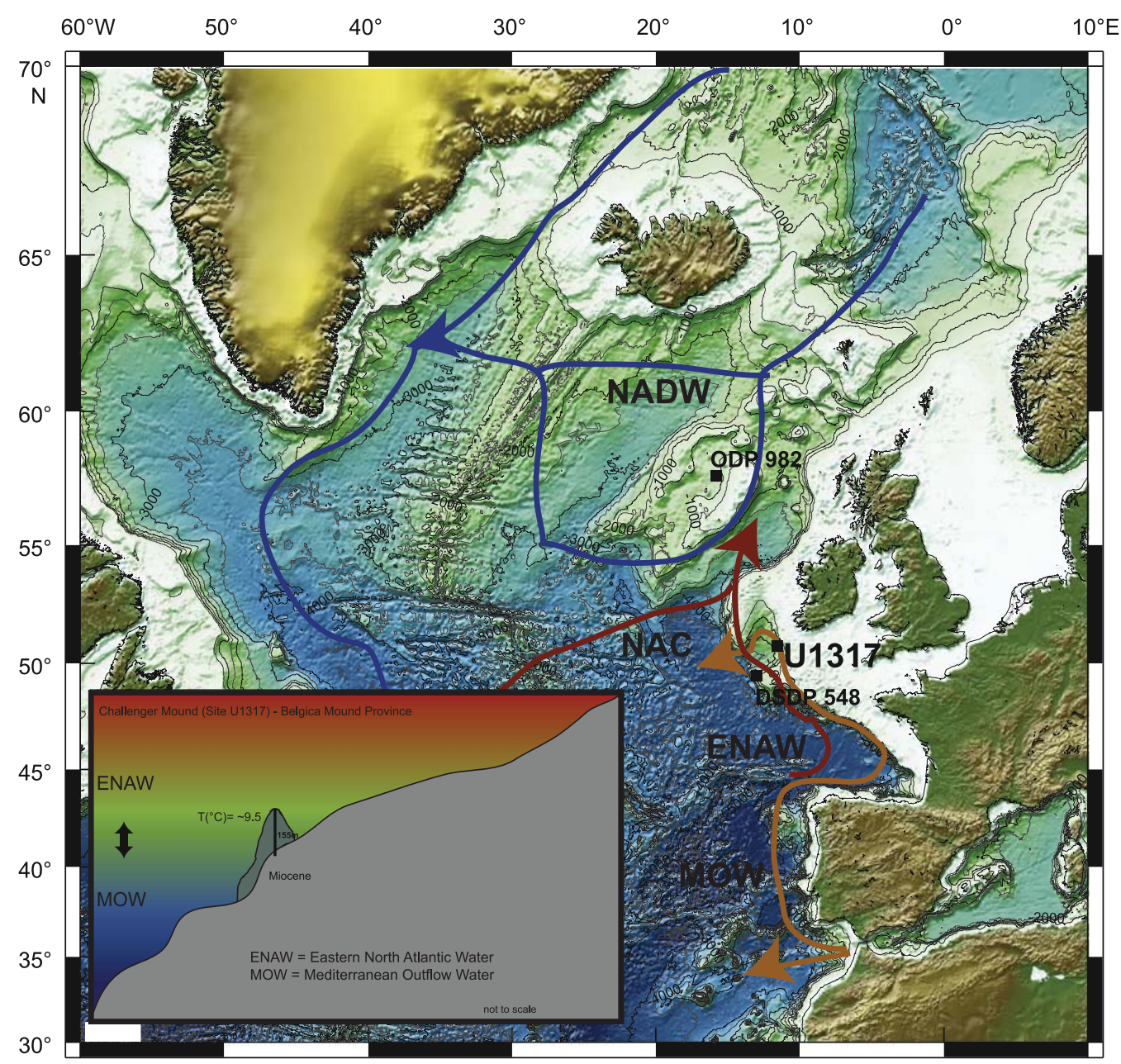

Fig. 1. Map showing the North Atlantic with the core location IODP Site 1317 in the Porcupine Seabight. Also shown are the Sites DSDP 548 and ODP 982 . The orange arrow indicates the flow of the Mediterranean Outflow Water (MOW), the red arrow of the Eastern North Atlantic Water (ENAW) and the North Atlantic Current (NAC) and the blue arrow the North Atlantic Deep Water (NADW). The small figure shows a schematic sketch of the seismic profile of the Challenger Mound on the slope of the Porcupine Seabight and the corresponding intermediate water masses (MOW and ENAW) with the modern annual mean Bottom-Water-Temperature of 9.5 ${ }^{\circ} \mathrm{C}$ (White, 2007). (For interpretation of the references to colour in this figure legend, the reader is referred to the web version of this article.) 

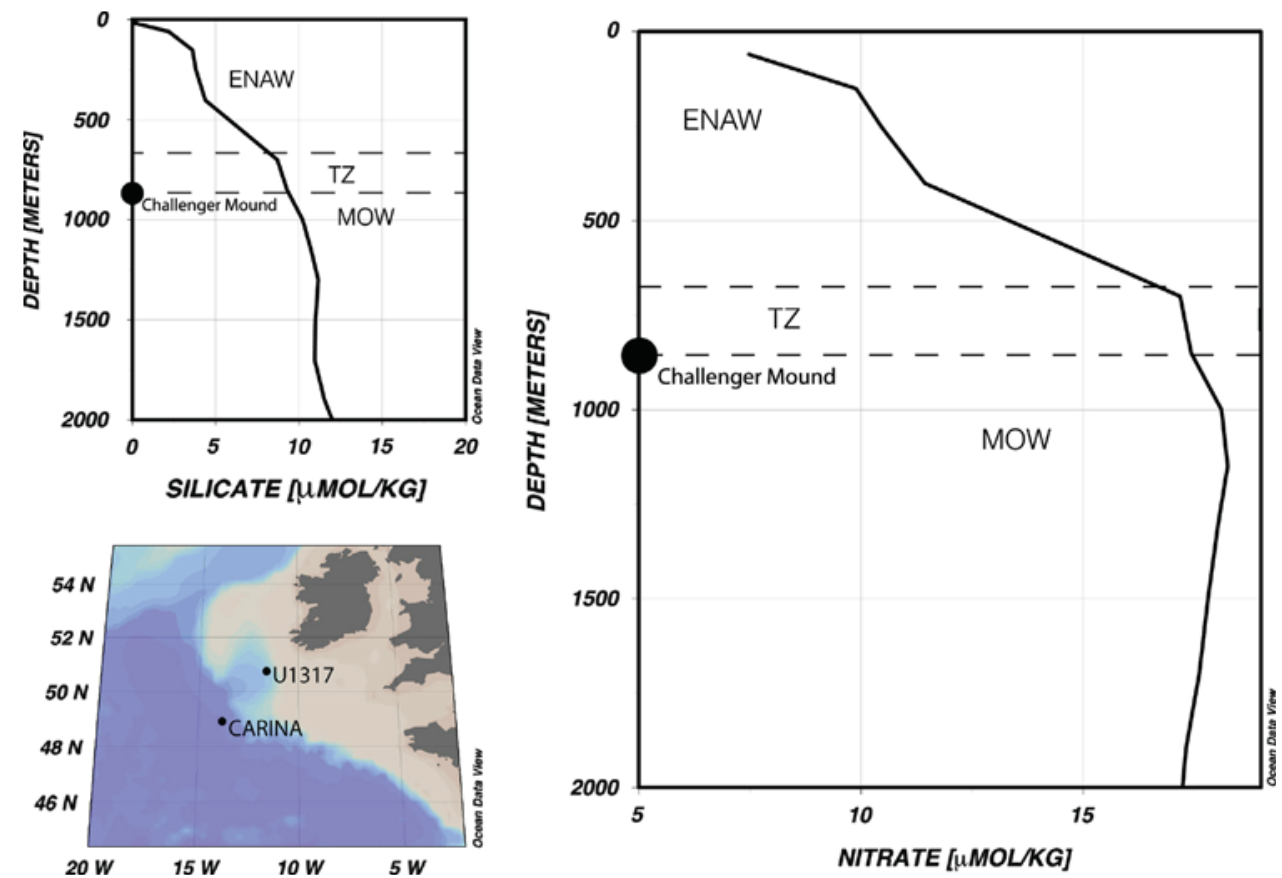

Fig. 2. Water column profiles of silicate and nitrate show increasing concentrations with greater water depth. Within the Transition Zone (TZ) of the Eastern North Atlantic Water (ENAW) and the Mediterranean Outflow Water (MOW) silicate and nitrate are characterised by a quasi plateau. Data were sourced from the public accessible CARINA ocean databases (CARINA Group, 2009) (http://cdiac.ornl.gov/oceans/) and plotted with Ocean Data View (Schlitzer (2012) - http://odv.awi.de).

ratio for paleotemperature reconstructions in the skeleton of the cold-water coral $L$. pertusa. We apply the equation of Hathorne et al. (2013) to calculate the Bottom-Water-Temperature (BWT) as it combines all available $\mathrm{Li} / \mathrm{Mg}$ temperature calibration including scleractinian cold- and warm-water corals.

$\mathrm{Li} / \mathrm{Mg}_{\text {coral }}=5.16 \mathrm{e}^{-0.0492 \mathrm{BWT}}\left(r^{2}=0.97\right)$

Dissolved barium has a similar distribution as nutrient and silicate concentrations in the water column (Fig. 2). It is depleted in the surface by biological activity and gets enriched towards the seafloor (Chan et al., 1977). In open ocean conditions barium has been used as a proxy for paleoproductivity (e.g. Dymond et al., 1992; Nürnberg and Tiedemann, 2004). The Ba/Ca ratios measured in marine carbonates have been used to reconstruct changes in ocean circulation, upwelling and nutrients (e.g., Lea et al., 1989; Lea and Boyle, 1991). Subsequently, Ba/Ca ratios were introduced as a nutrient tracer in cold-water corals (Montagna et al., 2005; Anagnostou et al., 2011; LaVigne et al., 2011) as they are not related to seawater temperature (Anagnostou et al., 2011). In particular, Anagnostou et al. (2011) demonstrated that the Ba/Ca ratio measured in the scleractinian cold-water coral Desmophyllum dianthus serves as a proxy for the reconstruction of $\mathrm{Ba} / \mathrm{Ca}_{\text {seawater }}$ and hence records variations in nutrient supply. In this study, $\mathrm{Ba} / \mathrm{Ca}$ ratios were used to calculate $\mathrm{Ba} / \mathrm{Ca}_{\mathrm{sw}}$ ratios according to Anagnostou et al. (2011):

$\mathrm{Ba} / \mathrm{Ca}_{\text {coral }}=1.4( \pm 0.3) \times \mathrm{Ba} / \mathrm{Ca}_{\mathrm{sw}}+0( \pm 2)$

We are aware of the use of $D$. dianthus for this calibration (Anagnostou et al., 2011), however we use the same calibration on L. pertusa to reconstruct trends and not absolute values.

\subsection{The Challenger Mound (Site U1317)}

In 2005 IODP Expedition 307 drilled for the first time through the entire sediment body of a cold-water coral mound, and obtained complete records of $155 \mathrm{~m}$ high Challenger Mound, located in the Porcupine Seabight (Site U1317, 52 $23^{\prime} \mathrm{N}, 11^{\circ} 43^{\prime} \mathrm{W}$; $\sim 800 \mathrm{~m}$ below sea level, Fig. 1, Williams et al., 2006). The recovered sediment cores contained mainly the scleractinian cold-water coral $L$. pertusa and only to a minor degree M. oculata. The mound is situated on top of an unconformity with a Miocene age of up to 16.58 Ma (Louwye et al., 2007; Kano et al., 2007). The sedimentary record of the Challenger Mound can be subdivided into two units, respectively M1 between 155 and $23.6 \mathrm{~m}$ below seafloor (mbsf) and M2 between 23.6 and 0 mbsf for Hole $1317 \mathrm{E}$ (Expedition 307 Scientists, 2006; Thierens et al., 2010; Titschack et al. 2009). Challenger Mound stratigraphic work carried out by Kano et al. (2007), (Strontium Isotope Stratigraphy (SIS)) shows that mound growth initiated at $\sim 2.6 \mathrm{Ma}$, whereas ages based on magnetostratigraphy point to an earlier onset at $>2.74 \mathrm{Ma}$ (Foubert and Henriet, 2009). Nevertheless, both studies recognised a significant hiatus at around $23.6 \mathrm{mbsf}$ in Site U1317 Hole E. This major hiatus separates the mound record into a period of fast $(\sim 15 \mathrm{~cm} / \mathrm{kyr}$ : 2.6-1.7 $\mathrm{Ma}=\mathrm{M} 1)$ and slower mound growth $(\sim 5 \mathrm{~cm} / \mathrm{kyr} 1.0$ $0.5 \mathrm{Ma}=\mathrm{M} 2$ ).

Here we compare the oceanographic settings in times of rapid Challenger Mound initiation versus mound decline. Based on new age constraints (combined $\mathrm{U} / \mathrm{Th}$ and ${ }^{87} \mathrm{Sr} /{ }^{86} \mathrm{Sr}$ ) and different geochemical signals from coral skeletons $(\mathrm{Mg} / \mathrm{Li}$ and $\mathrm{Ba} / \mathrm{Ca})$ this study contributes to the understanding of environmental and oceanographic boundary conditions required for cold-water coral mound growth in the Northeast Atlantic and adds to the debate if intermediate water masses had an impact on these deep-sea organisms and ecosystems throughout the last $3 \mathrm{Myr}$.

\section{Material and methods}

Coral fragments from Site U1317 recovered during IODP Expedition 307 with R/V Joides Resolution in 2005 (Expedition 307 Scientists, 2006) were investigated in this study. In order to obtain undamaged half core sections, the drill cores were frozen before splitting (Dorschel et al., 2005; Foubert et al., 2007). IODP Site 1317 consists of 5 different holes A, B, C, D and E. In this study we used samples from Holes B, C, D and E. For example at 147.95 mbsf sediments from Hole U1317C are characterised by an 


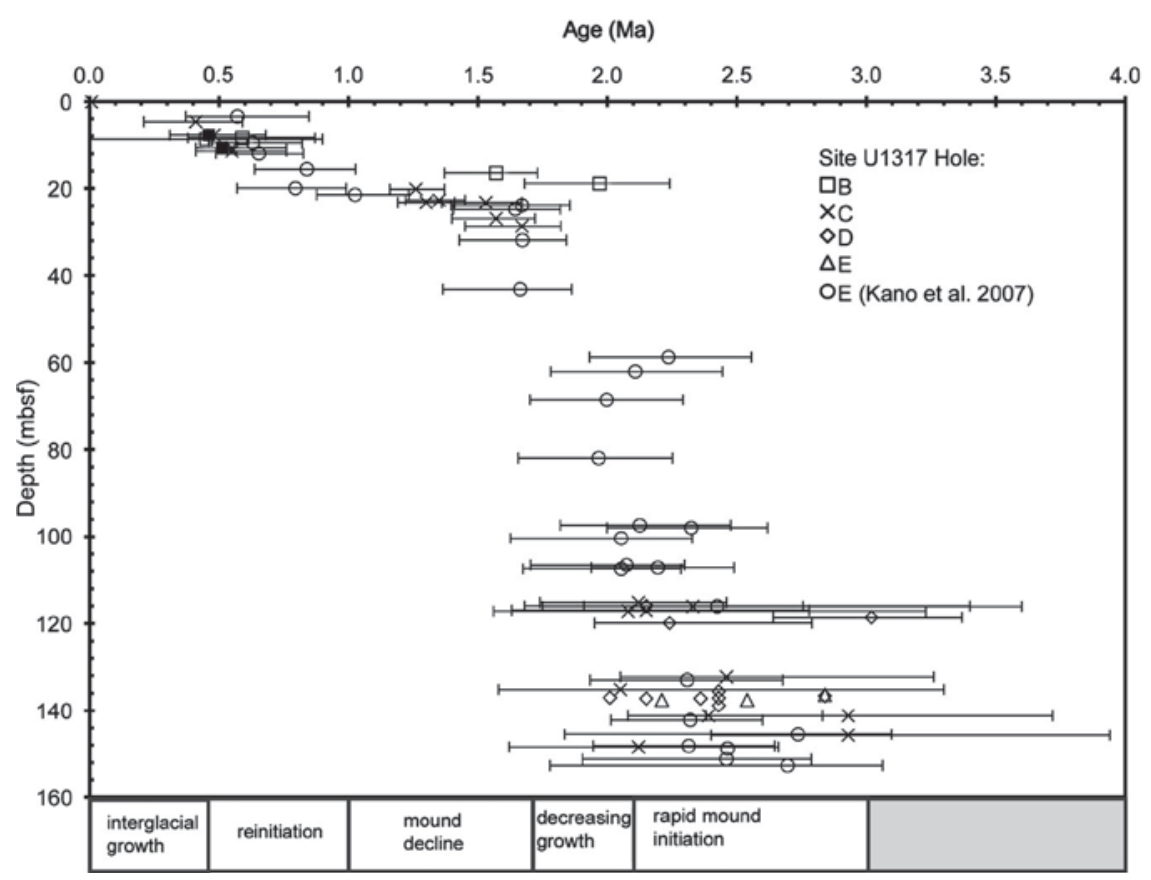

Fig. 3. Age constraints of the Challenger Mound showing the strontium isotope based ages for Site U1317 (Holes B, C, D, and E) and the published Sr-Ages of Kano et al. (2007) for Hole E. The SIS reveals that the decline of mound growth occurred at least in Holes B, C, and E.

unconformity, marked by a sharp colour change from the greenish-grey underlying unit to the grey, coral bearing sediments. Clean and well-preserved coral samples were taken from the base of Holes C, D and E (148-115 mbsf) and from 0-30 mbsf of Holes B and $\mathrm{C}$ for age determination and elemental ratio analyses. In addition, also one modern (in-situ, live collected, M61/3-551) $L$. pertusa sample from the nearby Galway Mound ( $837 \mathrm{~m}$ water depth, $9.5^{\circ} \mathrm{C}$ ) was also analysed for elemental/Ca ratios. All samples were drilled according to Rüggeberg et al. (2008) avoiding the centres of calcification, since these parts of the skeleton have different isotopic and elemental compositions compared to the rest of the skeleton. X-ray diffraction did exclude potential early diagenesis as all coral samples retain their initial aragonitic skeleton ( $>98 \%$ aragonite, below detection limit). Before analyses corals were cleaned according to Cheng et al. (2000a), but leaving out the reductively cleaning step after Shen and Boyle (1988). Briefly, corals were physically cleaned with a Proxxon dremel tool and all evidence (very rare) for endolithic organisms and potential bio-erosion were drilled out as far as possible. Subsequently, corals were ultrasonically cleaned several times (2-3) according to samples cleanness. Corals were then submerged into a 50/50 mixture $1 \mathrm{M} \mathrm{NaOH}$ and $30 \% \mathrm{H}_{2} \mathrm{O}_{2}$ for 15 min. with ultrasonification. This step was repeated several $(>2)$ times. Finally corals were rinsed in a $50 / 50$ mixture of $30 \%$ peroxide and $1 \% \mathrm{HCLO}_{4}$ for maximum of $1 \mathrm{~min}$.

\subsection{Strontium isotope stratigraphy on coral fragments}

Strontium isotope ratios were determined by Thermal Ionisation Mass Spectrometry (TIMS, TRITON, ThermoFisher Scientific) after chemical separation via cation exchange chromatography using a Srspecific resin (Eichrom). For $\mathrm{Sr}$ isotope measurements about $500 \mathrm{ng}$ of $\mathrm{Sr}$ was used. All isotope ratios were internally normalised to an ${ }^{88} \mathrm{Sr} /{ }^{86} \mathrm{Sr}$ ratio of 0.1194 . Repeated analysis of the standard NIST SRM 987 in the course of this study yielded an average value of $0.710245 \pm 12(2 \sigma, n=15)$. For comparison to literature values all ${ }^{87} \mathrm{Sr} /{ }^{86} \mathrm{Sr}$ were normalised to a value of 0.710248 for the NIST SRM 987. Ages were obtained by comparison to the seawater evolution curve (Lookup Table Version 4B-08-04, McArthur and Howarth, 2004, Age data: GTS 2004, Gradstein et al., 2004).

\subsection{Thorium/Uranium age determinations on coral fragments}

The Thorium and Uranium isotope measurements were performed on a VG Elemental AXIOM MC-ICP-MS at GEOMAR applying the approach of Fietzke et al. (2005). For isotope dilution measurements a combined ${ }^{233 / 236} \mathrm{U} /{ }^{229}$ Th-spike was used, with stock solutions calibrated for concentration using NIST-SRM 3164 (U) and NIST-SRM 3159 (Th) as combi-spike calibrated against CRM-145 uranium standard solution (also known as NBL-112A) for U-isotope composition, and against a secular equilibrium standard (HU-1, uranium ore solution) for determination of ${ }^{230} \mathrm{Th} /{ }^{234} \mathrm{U}$ activity ratio. Whole procedure blank values of this sample set were around $0.0006 \mathrm{pg}$ for ${ }^{230} \mathrm{Th}, 2 \mathrm{pg}$ for ${ }^{232} \mathrm{Th}$ and around $2 \mathrm{pg}$ for $\mathrm{U}$, which are in the typical range of this method and laboratory. Element separation procedure was based on Eichrom-UTEVA resin. Calculation of geochronological data and activity ratios is based on the decay constants given by Cheng et al. (2000b).

\subsection{Elemental ratio determinations on coral fragments}

Selected samples of the cold-water coral powders used for ${ }^{87} \mathrm{Sr} /{ }^{86} \mathrm{Sr}$ and ${ }^{230} \mathrm{Th} / \mathrm{U}$ age determinations measurements were split for additional ICP-MS measurements (Agilent 7500 CS). The Elemental/Ca ratios were calculated from the raw counts using the method of Rosenthal et al. (1999). Calcium concentrations were measured in a first step and samples diluted to a Ca concentration of $\sim 10 \mathrm{ppm}$. Six aliquots of Porites sp. coral powder reference material JCp-1 (Okai et al., 2002) were treated like samples and the average values obtained during the course of this study ( $n=8$, including repeated measurements) for $\mathrm{Mg} / \mathrm{Ca} 4.17 \pm 0.03 \mathrm{mmol} / \mathrm{mol}$, Li/Ca $6.17 \pm 0.18 \mu \mathrm{mol} / \mathrm{mol}$, $\mathrm{Ba} / \mathrm{Ca} 7.19 \pm 0.36 \mu \mathrm{mol} / \mathrm{mol}$ resulting in an average value for $\mathrm{Mg} / \mathrm{Li}$ values of $0.67 \pm 0.02 \mathrm{~mol} / \mathrm{mmol}$. The reproducibility (2SD) of the measurements was $\sim 2.64 \%$ for $\mathrm{Mg} / \mathrm{Ca}, 10.1 \%$ for $\mathrm{Ba} / \mathrm{Ca}$ and $5.42 \%$ for Li resulting in $7.13 \%$ for the $\mathrm{Mg} / \mathrm{Li}$ ratio for the JCp-1 (2 SD). The absolute concentrations are within the uncertainty of the recommended values (Okai et al., 2004). 


\section{Results}

\subsection{Strontium isotope measurements}

Radiogenic strontium isotopes measurements were carried out on corals covering the upper (0-30 mbsf) and lower mound sequence (115-148 mbsf). Overall the ${ }^{87} \mathrm{Sr} /{ }^{86} \mathrm{Sr}$ isotope ratios vary from 0.709061 to 0.709174 and show an increasing trend from the lower to the upper mound part. In particular, ${ }^{87} \mathrm{Sr} /{ }^{86} \mathrm{Sr}$ isotope ratios in the interval between 110 and $148 \mathrm{mbsf}$ of M1 are similar and vary only between 0.70906 and 0.70908 . In contrast, in the interval between 0 and $30 \mathrm{mbsf}$ the ${ }^{87} \mathrm{Sr} /{ }^{86} \mathrm{Sr}$ isotope ratios increase from 0.70910 to 0.70917 . Corresponding ages were calculated after the Lookup Table Version 4B-08-04, McArthur and Howarth, 2004, Age data: GTS 2004 (Gradstein et al., 2004). Calculated Sr-ages reveal that the mound generally becomes younger from the base to the top. In particular the mound base shows ages between 3.02 and $2.01 \mathrm{Ma}$ (SIS mean age), whereas the upper mound interval displays ages between 0.008 and $1.67 \mathrm{Ma}$ (Fig. 3).

\section{2. $T h / U$ age determinations}

Calculated U-series ages of 16 corals vary from 1.2 to $513 \mathrm{ka}$ (Supplements). The measured ${ }^{232} \mathrm{Th}$ concentrations are small $<2 \mathrm{ng} \mathrm{g}^{-1}$ and hence negligible due to the high activity ratio of ${ }^{230} \mathrm{Th} /{ }^{232} \mathrm{Th}$ of $>1000$. However, calculated initial $\delta^{234} \mathrm{U}_{0}$ values vary between 15.6 and 156.84 (Supplements).

Four samples are within the range of $149.6 \pm 10 \%$ (compare Stirling et al., 1998; Robinson et al., 2004) and show ${ }^{230} \mathrm{Th} / \mathrm{U}$ ages similar to the Sr-ages (Fig. 4). The ${ }^{230} \mathrm{Th} / \mathrm{U}$ dated coral growth occurs generally in interglacial periods at $1.2 \mathrm{ka} \pm 0.002$ (MIS 1 ), $104.7 \pm 0.7 \mathrm{ka}$ (MIS 5) and 513.9 \pm 35.2 (MIS 13). The coral based ages at 460.2 (MIS 12) might also be assigned to an interglacial period, due to the large uncertainty of $\pm 63 \mathrm{ka}$.

The $\delta^{234} U_{0}$ scatter for the older samples is larger, compared to the younger samples probably due to more open system behaviour (Thompson et al., 2003). The study of Titschack et al. (2009) reported many hiatuses in the upper mound M2 interval, therefore we assume that corals, indicating open system behaviour, could have been exposed at the sediment/seawater interface for extended periods and may have been affected by pore waters. Future studies will focus on more detailed analysis of the U-series data including uncertainties of potential seawater U-isotopic variations, diagenetic alteration and U-series system opening, but this is beyond the scope of this study and will be presented elsewhere.

For further geochemical investigations corals indicating opensystem behaviour were not used for paleoceanographic reconstruction. However, corals from the lower mound sequence were not measured for Thorium/Uranium. Here, the quality of coral samples is only based on XRD measurements, which imply the rather good preservation of the studied coral fragments from the lower mound sequence M1.

\subsection{Elemental ratios of coral skeletons}

Downcore $\mathrm{Mg} / \mathrm{Ca}$ ratios vary from 2.32 to $3.89 \mathrm{mmol} / \mathrm{mol}$ and the corresponding Li/Ca values range from 7.57 to $15.75 \mu \mathrm{mol} / \mathrm{mol}$. The calculated $\mathrm{Mg} / \mathrm{Li}$ ratios presented here vary from 0.23 to $0.32 \mathrm{~mol} /$ mmol with a mean of $0.28 \mathrm{~mol} / \mathrm{mmol}$ in the entire mound sequence. In general the $\mathrm{Mg} / \mathrm{Li}$ ratios display an increasing trend from the mound base to the top mound from 0.23 to $0.32 \mathrm{~mol} / \mathrm{mmol}$ (Fig. 5). The same pattern is observed in the $\mathrm{Li} / \mathrm{Ca}$ record. Overall, the $\mathrm{Mg} / \mathrm{Ca}$ and $\mathrm{Li} / \mathrm{Ca}$ ratios are in phase with the observed modern values of scleractinian cold-water corals (Case et al., 2010) and display the expected positive relationship indicating that the corresponding $\mathrm{Mg} / \mathrm{Li}$ ratios are not disturbed by any potential diagenetic overprint (Fig. 6). We used the temperature relationship of $\mathrm{Mg} / \mathrm{Li}(\mathrm{Li} / \mathrm{Mg}$ ) ratios (Hathorne et al., 2013) in L. pertusa to calculate the BWT of the ambient seawater during times of coral growth (Fig. 7). Reconstructed BWT show an increasing trend from the mound base to the top mound from $\sim 7.9$ to $9.6^{\circ} \mathrm{C}$ for $\mathrm{Mg} / \mathrm{Li}$ (Fig. 7).

Recent studies have highlighted that both $\mathrm{Mg} / \mathrm{Li}$ and $\mathrm{Li} / \mathrm{Ca}$ ratios may serve as a potential paleotemperature proxy in scleractinian corals (Case et al., 2010; Montero-Serrano et al., 2013; Hathorne et al., 2013). However, $\mathrm{Mg} / \mathrm{Li}$ ratios, introduced by the study of Bryan and Marchitto (2008), are suggested to be more robust since they show less heterogeneity within the coral skeleton compared to Li/Ca (Case et al., 2010; Hathorne et al., 2013).

As we aim to reconstruct paleotemperatures over a relatively long period of time ( $\sim 3$ Myrs) the elemental and isotopic composition of seawater has to be considered as this may result in over and/or underestimated paleotemperatures. In particular, the

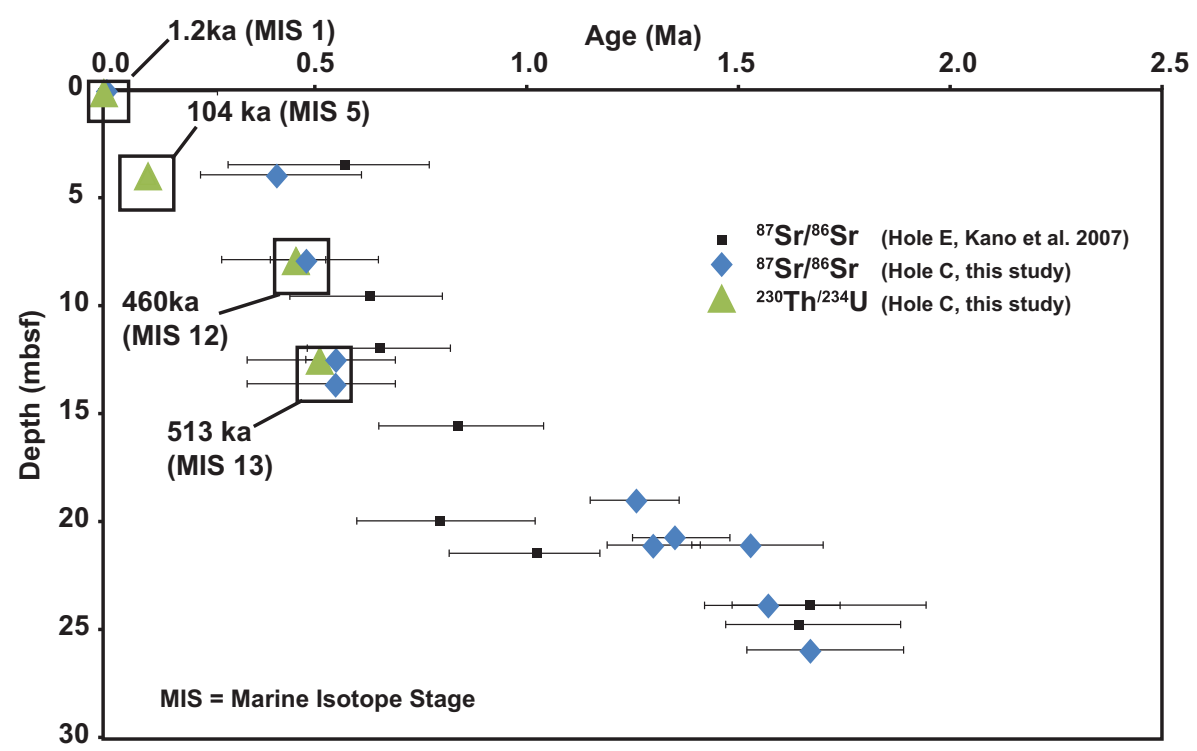

Fig. 4. Coral skeleton based age determinations by the use of ${ }^{87} \mathrm{Sr} /{ }^{86} \mathrm{Sr}$ and ${ }^{230} \mathrm{Th} / \mathrm{U}$ at IODP Site 1317 . On the top of the mound both chronometers show within uncertainty similar ages indicating that ages are reliable. 


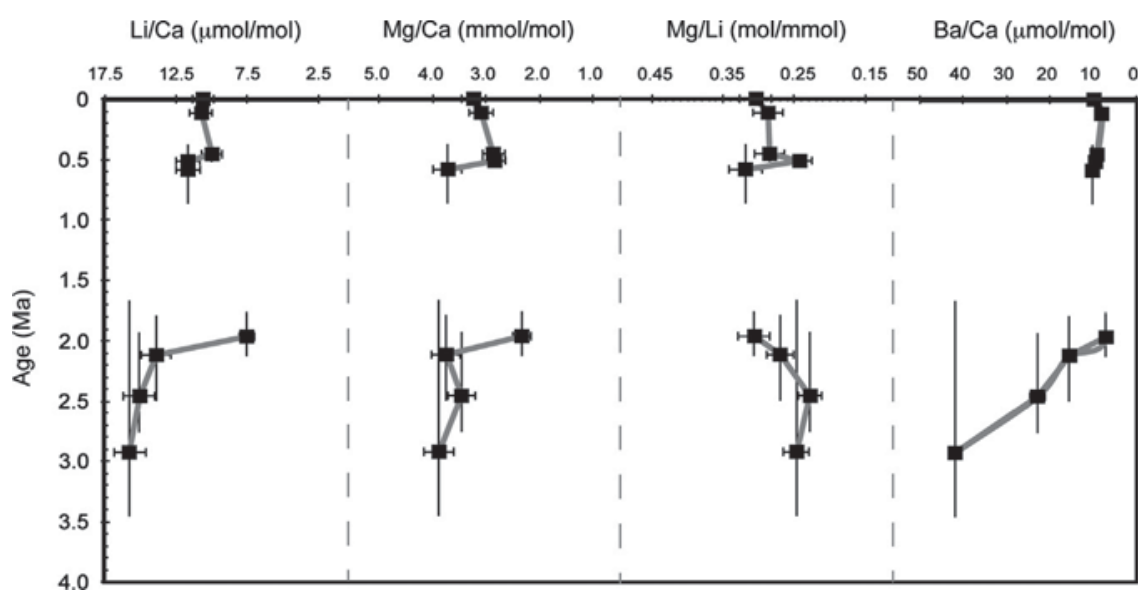

Fig. 5. Downcore records over the last 3 Myrs of coral $\mathrm{Mg} / \mathrm{Ca}, \mathrm{Li} / \mathrm{Ca}, \mathrm{Mg} / \mathrm{Li}$ and $\mathrm{Ba} / \mathrm{Ca}$ ratios. Overall, the $\mathrm{Mg} / \mathrm{Li}$ and $\mathrm{Ba} / \mathrm{Ca}$ ratios show a gradual trend from the lower mound to the top.

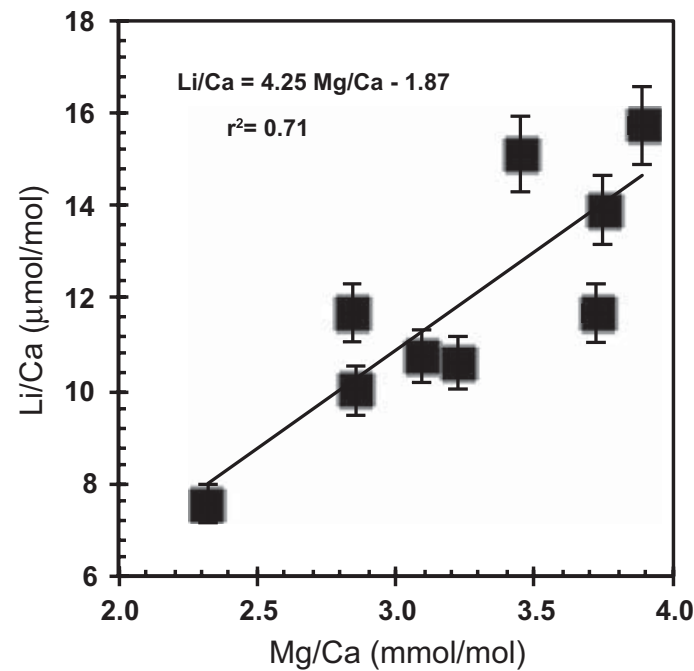

Fig. 6. Coral-based downcore records of $\mathrm{Mg} / \mathrm{Ca}_{\text {Lophelia }}$ and $\mathrm{Li} / \mathrm{Ca}_{\text {Lophelia }}$ ratios showing a correlation of $r^{2}=0.71$ indicating no diagenetic overprint in the fossil L. pertusa skeletons.

$\mathrm{Mg} / \mathrm{Li}$ is calculated from the $\mathrm{Mg} / \mathrm{Ca}$ and $\mathrm{Li} / \mathrm{Ca}$ ratio. For Magnesium and Lithium it was suggested that the seawater value has been increased similar by a factor of 2 over the last 3 Myrs (Hathorne and James, 2006; Fantle and DePaolo 2006; Coggon et al. 2010). Therefore, we assume the seawater $\mathrm{Mg} / \mathrm{Li}$ ratio to be constant. Moreover, the impact of a variable $\mathrm{Mg} / \mathrm{Li}_{\text {seawater }}$ ratio on the coral $\mathrm{Mg} / \mathrm{Li}$ ratio is not known. Hence, we do not consider a change in the $\mathrm{Mg} / \mathrm{Li}_{\text {seawater }}$ ratio for the temperature reconstructions.

The coral Ba/Ca record displays an overall mean of $14.83 \mu \mathrm{mol} /$ mol with a maximum of $41.79 \mu \mathrm{mol} / \mathrm{mol}$ in $\mathrm{M} 1$ and a minimum of $7.11 \mu \mathrm{mol} / \mathrm{mol}$ in M2. Generally the interval M1 is characterised by higher $\mathrm{Ba} / \mathrm{Ca}_{\text {Lophelia }}$ values with a mean of $\sim 20 \mu \mathrm{mol} / \mathrm{mol}$, whereas the mean of $\mathrm{Ba} / \mathrm{Ca}_{\text {Lophelia }}$ values in $\mathrm{M} 2$ is lower with $9.23 \mu \mathrm{mol} / \mathrm{mol}$ (Fig. 5). Calculated $\mathrm{Ba} / \mathrm{Ca}_{\mathrm{sw}}$ values show a similar pattern (Fig. 7).

Special cleaning methods were proposed to avoid potential contamination with barytes (Lea and Boyle 1991), which would increase the $\mathrm{Ba} / \mathrm{Ca}$ ratio. Nevertheless, except for the oldest sample, our measured $\mathrm{Ba} / \mathrm{Ca}$ ratios are consistent with recent measurements on $L$. pertusa from the nearby Galway Mound $(8.13 \mu \mathrm{mol} / \mathrm{mol}$, Fig. 7) in the Porcupine Seabight and to the $\mathrm{Ba} /$ Ca calibration of Anagnostou et al. (2011). This indicates that our cleaning method was sufficient to reduce potential biases by barytes in the coral aragonite.

\section{Discussion}

\subsection{Stratigraphy of the Challenger Mound}

In the North Atlantic, carbonate mound growth initiated in several phases since the Pliocene (Van Weering et al., 2003, Mienis et al., 2006; Van Rooij et al., 2007), nevertheless the exact timing of first initiation remains unclear. First ${ }^{87} \mathrm{Sr} /{ }^{86} \mathrm{Sr}$ age determinations on $L$. pertusa fragments and magnetostratigraphy dates reveal that the Challenger Mound initiated $\sim 2.6-2.9$ Ma (Kano et al., 2007; Foubert and Henriet, 2009). Our radiogenic Sr-based stratigraphy is similar to those findings indicating that coral mound growth initiated at the Pliocene/Pleistocene boundary (Fig. 3). Mound initiation in the Porcupine Seabight has been earlier related to the late Pliocene reintroduction of the Mediterranean Outflow Water into the Porcupine Seabight (De Mol et al., 2002). This is in good accordance with the study of Khélifi et al. (2009) showing that the MOW intensified between 3 and $3.5 \mathrm{Ma}$ in the Porcupine Seabight (DSDP Site 548, Fig. 1). Therefore, intermediate water mass dynamics are crucial for the build-up and development of cold-water coral carbonate mounds at the Porcupine Seabight margins (Raddatz et al., 2011).

The early development of Challenger Mound in M1 was fast and rather continuous (Mound Booster Stage; Henriet et al., 2002) and hence indicates that initial environmental conditions until $\sim 2.0$ $2.1 \mathrm{Ma}$ were favourable for cold-water coral growth (Fig. 3). This period of fast initial mound development in the early Pleistocene was characterised by weak sea-level fluctuations triggered by the orbital low-amplitude 41-ka cycle (Lisiecki and Raymo, 2005). The growth patterns for Challenger Mound have been described by several studies (Kano et al., 2007; Foubert and Henriet, 2009; Huvenne et al., 2009; Thierens et al., 2010). Mound growth started to cease at $\sim 2 \mathrm{Ma}$ and at $\sim 1 \mathrm{Ma}$. This growth behaviour was already identified by other studies (Kano et al., 2007; Foubert and Henriet, 2009; Sakai et al., 2009; Titschack et al., 2009). During this growth decline Challenger Mound was only partly covered by corals (Kano et al., 2007). These findings are supported by the ${ }^{87} \mathrm{Sr} /{ }^{86} \mathrm{Sr}$ ages presented here showing that coral mound growth in this crucial period was reduced but did not entirely cease (Fig. 3 ).

For the top mound part we applied a combined age determination using ${ }^{230} \mathrm{Th} / \mathrm{U}$ and ${ }^{87} \mathrm{Sr} /{ }^{86} \mathrm{Sr}$ ages. Kano et al. (2007) documented Sr ages until $\sim 0.6 \mathrm{Ma}$ at $4 \mathrm{mbsf}$ in Hole E, whereas our ${ }^{87} \mathrm{Sr} /{ }^{86} \mathrm{Sr}$ ages of Hole C (0.1 mbsf) and B (8.37 mbsf) reveal younger ages (Fig. 3). In particular, from $13 \mathrm{mbsf}$ to the top of the Challenger Mound $\mathrm{Sr}$ ages generally become younger again and show ages between $0.5 \mathrm{Ma}$ and 0 . However, mound growth in the upper mound part M2 appears not to be as fast as in the lower mound part M1. Early 


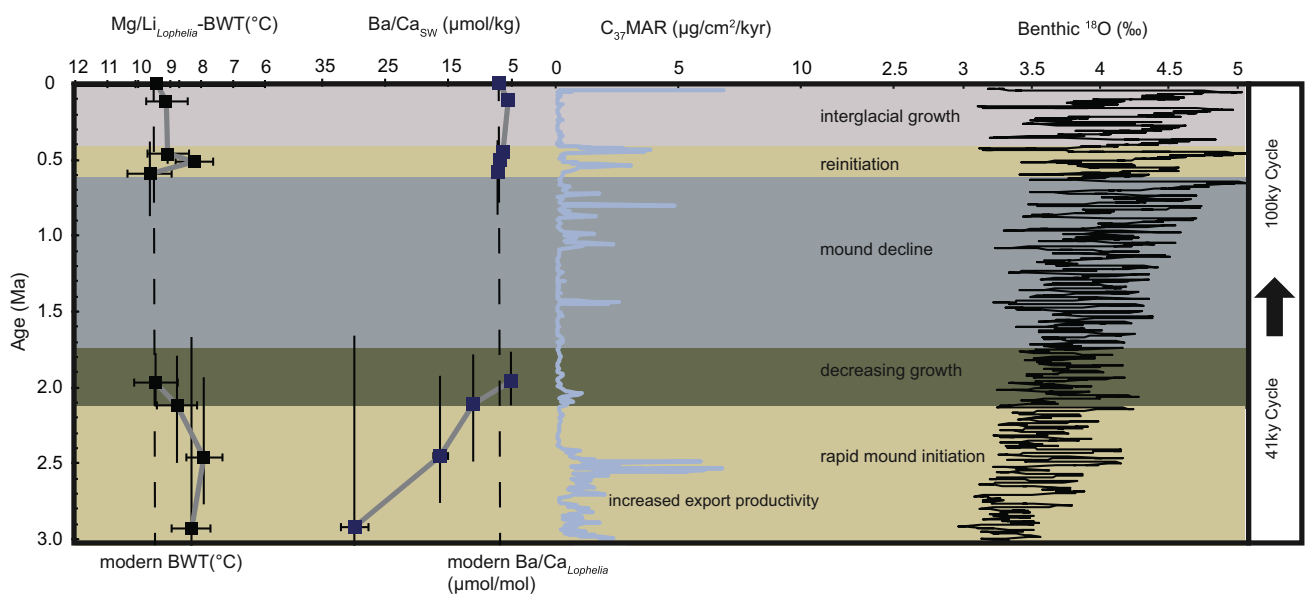

Fig. 7. Paleoceanographic reconstruction based on ${ }^{230} \mathrm{Th} / \mathrm{U}$, and ${ }^{87} \mathrm{Sr} /{ }^{86} \mathrm{Sr}$ dated corals. Elemental ratios were measured in scleractinian cold-water coral $L$. pertusa. The Mg/ $\mathrm{Li}_{\text {Lophelia }}$ ratios were transferred into BWT using the equation of Hathorne et al. (2013). Results show that corals thrived in a temperature envelope between 8 and $10{ }^{\circ} \mathrm{C}$ comparable to the modern BWT $\left(9.5^{\circ} \mathrm{C}\right.$ dashed line; White, 2007). The Ba/Ca $\mathrm{a}_{\text {Lophelia }}$ were transferred into Ba/Ca of seawater based on the study of Anagnostou et al. (2011) showing a clear shift towards lower values from the lower to the upper mound. The dashed line illustrates the recent Ba/Ca $a_{\text {Lophelia }}$ values from the nearby Galway Mound. The $C_{37}$ MAR based reconstructions of export productivity from ODP Site 982 are taken from Bolton et al. (2011). Also plotted is the benthic LR04 stack of Lisiecki and Raymo (2005) showing the increase of amplitudes in interglacial/glacial cycles over the last 3 Myr.

mound development (M1) of Challenger Mound between 3.0 and 2.1 Ma was characterised by an initial period of fast mound growth with depositional rates of $\sim 15 \mathrm{~cm} / \mathrm{ka}$ and a second period with lower growth at rates of $<1 \mathrm{~cm} / \mathrm{ka}$. The depositional rate of the upper mound M2 is remarkably lower with $\sim 2 \mathrm{~cm} / \mathrm{ka}(1.2-0.001 \mathrm{Ma}$, Kano et al., 2007; Titschack et al., 2009).

Furthermore, our results indicate that both age chronometers are - within uncertainty - in good accordance with each other (Fig. 4). The ${ }^{230} \mathrm{Th} / \mathrm{U}$ ages presented here reveal that Challenger Mound growth in the late Pleistocene occurred only in Interglacial periods, except for MIS 12 (Fig. 4). A significant hiatus is identified at $\sim 4$ mbsf revealing a period of no deposition and/or erosion of $\sim 0.3 \mathrm{Ma}$ between MIS 5 and MIS 12. This interpretation is consistent with the findings of Foubert et al. (2007) indicating the same hiatus in gravity cores on Challenger Mound, and Titschack et al. (2009) who highlighted that the sedimentary record might be disturbed by several hiatuses. Other studies have shown that carbonate mound growth on the Irish margin in the Latest Pleistocene was restricted to interglacial periods (Dorschel et al., 2005; Eisele et al., 2008; Frank et al., 2005, 2009, 2011; Rüggeberg et al., 2007) with only a few exceptions. Further south in the Bay of Biscay cold-water coral growth tends to have occurred during interstadials (SchröderRitzrau et al., 2005). In the Gulf of Cadiz (Wienberg et al., 2009, 2011) as well as off Mauritania (Eisele et al., 2011; Frank et al., 2011) growth is observed during glacials. Focusing on the very top of the Challenger Mound ${ }^{230} \mathrm{Th} / \mathrm{U}$ age determinations show that cold-water coral growth was indeed only active during interglacials, namely MIS 1 and MIS 5. Since the Mid-Pleistocene-Transition interglacial/glacial cycles are dominated by a $100 \mathrm{ka}$ periodicity, characterised by changes in sea level of $\sim 120 \mathrm{~m}$ (Lisiecki and Raymo, 2005).

We therefore suggest that similar to other cold-water coral carbonate mounds on the Irish margin (Dorschel et al., 2005; Eisele et al., 2008; Frank et al., 2005, 2009, 2011; Rüggeberg et al., 2007) pronounced glacial/interglacial changes during these periods had an important impact on mound growth. Overall, the growth of the Challenger Mound seems to have been connected to major global climatic changes, such as the intensification of the Mediterranean Outflow Water (Khélifi et al., 2009), the Northern Hemisphere Glaciation and the Mid-Pleistocene Transition (Mudelsee and Schulz, 1997). Moreover, from our observation it appears that the restriction of carbonate mound growth to interglacial periods at around $50^{\circ} \mathrm{N}$ on the Irish Margin is at least valid for the last $\sim 0.5 \mathrm{Myr}$, but does not apply for the early growth stages of Challenger Mound (Raddatz et al., 2011).

\subsection{Environmental boundary conditions of cold-water} coral mound growth

Environmental control mechanisms of cold-water coral reef growth and mound build-up on the European continental margin between $20^{\circ}$ and $70^{\circ} \mathrm{N}$ are currently the subject of ongoing paleoceanographic research. Recent studies have shown that late Pleistocene distribution of flourishing coral-reefs and mounds oscillated from the NE Atlantic down to the Gulf of Cadiz and off Mauretania in correspondence to Interglacial/Glacial cycles induced by the expansion and retreat of the Northern-Hemisphere ice-sheets (Dorschel et al., 2005; Eisele et al., 2008; Frank et al., 2005, 2009, 2011; Rüggeberg et al., 2007; Wienberg et al., 2009, 2011; Thierens et al., 2010). Their biogeographical limitation is caused by (a combination of) changes in sea-surface productivity (Eisele et al., 2011; Wienberg et al., 2011), upwelling (Wienberg et al., 2011) and bottom currents (Rüggeberg et al., 2005; Huvenne et al., 2009), which in turn are affected by changes in (intermediate) water mass variability and dynamics. Strong bottom currents, enhanced seasurface productivity, temperatures above $4{ }^{\circ} \mathrm{C}$, and a prominent strong density gradient between the upper and intermediate water masses favoured coral growth during the last interglacial periods on the Irish Margin (Dorschel et al., 2005; Dullo et al., 2008; Eisele et al., 2008; Frank et al., 2005; Rüggeberg et al., 2007).

Our $\mathrm{Mg} / \mathrm{Li}_{-} \mathrm{BWT} \mathrm{T}_{\text {Lophelia }}$ reconstructions vary between $\sim 8$ and $10{ }^{\circ} \mathrm{C}$ and are consistent with the optimal temperature range of L. pertusa and the modern BWT in the Belgica Mound Province $\left(\sim 9.5^{\circ} \mathrm{C}\right.$, Fig. 7; White, 2007). Additionally, our results are also in good accordance with the $\mathrm{Mg} / \mathrm{Ca}$-based foraminiferal paleotemperatures from south of the Porcupine Seabight (DSDP Site 548) by Khélifi et al. (2009) and $\delta^{18}$ O-based foraminiferal paleotemperatures from IODP Site 1317C (Raddatz et al., 2011). Hence, we propose from our reconstructions that coral mound growth mainly occurred within the optimal BWT envelope between 8 and $10{ }^{\circ} \mathrm{C}$. We relate this to the inflow of the warm and saline MOW causing a specific temperature setting at intermediate water depth in the Porcupine Seabight. In general cold-water corals are known to thrive in cold and nutrient-rich water that lack large seasonal variability (Roberts et al., 2006) and active mound growth is restricted to specific environmental conditions (Rüggeberg et al., 2007). In the Porcupine Seabight a pycnocline is formed between the inflowing MOW and ENAW. This density gradient favours the settlement of organic matter providing sufficient nutrients for 
active cold-water coral growth, similar to recent observation at living coral reefs (Dullo et al., 2008). Today the majority of the living cold-water reefs and mounds in the Northeast Atlantic occur within a narrow density envelope and an associated permanent thermocline (Dullo et al., 2008; White and Dorschel, 2010). Corals benefit from organic matter that settles down from the sea-surface (Guinotte et al., 2006) and concentrates around this specific density envelope. White et al. (2005) investigated the productivity over the Porcupine Bank and concluded that coral growth depends on high sea-surface productivity and high utilisation of organic matter resulting in a dense nutrient rich water mass. In our records we observe a gradual trend in the reconstructed $\mathrm{Ba} / \mathrm{Ca}_{\mathrm{Sw}}$ values from $\sim 29$ to $\sim 10 \mu \mathrm{mol} / \mathrm{mol}$ (Fig. 7). We attribute this trend to a decrease in nutrient supply (Figs. 2 and 7) due to changes in sea-surface productivity and to a shifting water mass boundary between the ENAW and MOW (Figs. 2 and 3). A deepening of the MOW would lead to a stronger influence of the warmer nutrient depleted ENAW at the core summit (Fig. 7). Such a trend can be observed in our $\mathrm{Mg} / \mathrm{Li}_{\text {Lophelia }}$ temperature record revealing a temperature increase of $\sim 2{ }^{\circ} \mathrm{C}$ (Fig. 7). Such an increase of $2{ }^{\circ} \mathrm{C}$ cannot be explained by the growth of the coral mound $(155 \mathrm{~m})$ through the water column $\left(<0.5^{\circ} \mathrm{C}\right)$. However, the modern oceanography of Porcupine Seabight reveals that the top of the dead Challenger Mound is situated well above the boundary layer between the ENAW and the MOW, whereas other active mounds appear to occur deeper (Huvenne et al., 2003; Foubert et al., 2005). This implies that corals on the top of the Challenger Mound are not sufficiently provided by nutrients and food, leading to the recently observed decline or sparse growth of Challenger Mound.

This study indicates that in the past sea-surface productivity was also one of the major controlling parameters of cold-water coral growth. Enhanced primary sea-surface productivity in the North Atlantic can be associated with changes of the polar front at the Pliocene-Pleistocene boundary (Naafs et al., 2010; Bolton et al., 2011) and decreased sea-surface productivity during the Mid-Pleistocene Transition (MPT, Stein et al., 2009) to an enhanced impact of the British ice-sheets into the Porcupine Seabight (Thierens et al., 2010, 2012). These periods can be linked to crucial episodes of Challenger Mound growth or decline (Fig. 7). In particular, records from ODP Site 982 (Fig. 1) reveal that the North Atlantic was characterised by enhanced export productivity until $\sim 2.3 \mathrm{Ma}$ and between 1 and $0.4 \mathrm{Ma}$ (Fig. 7, Bolton et al., 2011).

Therefore, we suggest that enhanced export productivity may have caused an increased supply of organic matter and nutrients to the coral site. We infer that rapid coral mound growth benefited from a stable water mass stratification between the ENAW and the MOW which formed a density gradient similar to the modern density envelope (Dullo et al., 2008) close to the mound summit and hence formed a crucial boundary layer to provide the coral community with organic matter from the sea-surface.

The two-step decline of the coral community starting at around $\sim 2 \mathrm{Ma}$ was characterised by significant slower mound growth (Figs. 3 and 7). This crucial period corresponds to the MPT initiated due to enlarged ice-sheets (Mudelsee and Schulz, 1997) and increasing sea-level fluctuations (Lisiecki and Raymo, 2005). Moreover, this period is in phase with reduced export productivity (Bolton et al., 2011). We suggest that the reduced export productivity, in combination with a long-term lowering of the transition zone between ENAW and MOW, caused a gradually decreasing nutrient supply to the mound summit (Fig. 7). After the MPT at $\sim 1$ Ma enhanced export productivity in the North Atlantic (Bolton et al., 2011) and the water mass boundary between the ENAW and MOW at the mound summit favoured the re-initiation of rapid cold-water coral mound growth (Fig. 7). In the most recent glacial periods the presence of MOW was restricted to south of $40^{\circ} \mathrm{N}$ (Schönfeld and Zahn, 2000) and therefore the absence of the water mass stratification was leading to insufficient nutrient and food supply.

\section{Conclusion}

New age constraints indicate that Challenger Mound may have initiated as early as $3 \mathrm{Ma}$ following an intensification of the Mediterranean Outflow Water (MOW). Bottom-Water-Temperature (BWT) reconstructions by $\mathrm{Mg} / \mathrm{Li}_{\text {Lophelia }}$ ratios and nutrient reconstructions based on $\mathrm{Ba} / \mathrm{Ca}_{\text {Lophelia }}$ ratios reveal that coral growth was restricted to specific oceanographic settings. In particular coral and mound growth mainly occurred within a narrow temperature range between 8 and $10^{\circ} \mathrm{C}$. The MOW initiated the recent water mass stratification in the Porcupine Seabight that in turn established the necessary density gradient for enhanced nutrient and food supply between the Eastern North Atlantic Water (ENAW) and MOW at the mound summit. Between 1.7 and $1 \mathrm{Ma}$ mound development was reduced or interrupted coinciding with the Mid-Pleistocene-Transition, a period of global climate change. High amplitude interglacial/glacial cycles (100 ka) initiated and glacial conditions became unfavourable for corals in the Porcupine Seabight.

From our reconstructions we propose that coral growth benefited from a complex oceanographic setting that supported an enhanced nutrient and food supply. Finally, this study underlines that cold-water coral communities are restricted to specific environmental conditions (specific water mass stratification at intermediate water depths in combination with enhanced palaeoproductivity) and hence climate change may cause a dramatic decline in cold-water coral mound growth on the European continental margins.

\section{Acknowledgements}

We are gratefully thankful to the Captain and crew of the IODP Exp. 307 as well as the Scientific Party. Samples were kindly provided by IODP. Thanks to Walter Hale helping with the core sampling at the IODP Core Repository, Bremen. This work was funded by DFG Project ISOLDE I and II (Du 129/45-1 and Du 129/ 45-3). Folkmar Hauff, Jutta Heinze and Ana Kolevica are thanked for lab support. AR acknowledges funding from DFG project TRISTAN (Du 129/37) and FWO International Coordination Action COCARDE - ICA (G.OZ52-09.N). We thank Veerle Huvenne and Matthias López Correa whose comments improved the manuscript considerably. We are indebted to the guest-editors Tjeerd van Weering, Furu Mienis and Gerald Duineveld.

\section{Appendix A. Supporting information}

Supplementary data associated with this article can be found in the online version at http://dx.doi.org/10.1016/j.dsr2.2013.06.009.

\section{References}

Adkins, J.F., Cheng, H., Boyle, E.A., Druffel, E.R.M., Edwards, R.L., 1998. Deep-sea coral evidence for rapid changes in ventilation of the deep North Atlantic at $15.4 \mathrm{ka}$. Science 280, 725-728.

Anagnostou, E., Sherrell, R.M., Gagnon, A., LaVigne, M., Field, M.P., McDonough, W.F., 2011. Seawater nutrient and carbonate ion concentrations recorded as $\mathrm{P} / \mathrm{Ca}, \mathrm{Ba} / \mathrm{Ca}$, and U/Ca in the deep-sea coral Desmophyllum dianthus. Geochim. Cosmochim. Acta 75, 2529-2543, http://dx.doi.org/10.1016/j.gca.2011.02.019.

Bolton, C.T., Lawrence, K.T., Gibbs, S.J., Wilson, P.A., Herbert, T.D., 2011. Biotic and geochemical evidence for a global latitudinal shift in ocean biogeochemistry and export productivity during the late Pliocene. Earth Planet. Sci. Lett. 308, 200-210, http://dx.doi.org/10.1016/j.epsl.2011.05.046. 
Bryan, S.P., Marchitto, T.M., 2008. Mg/Ca-temperature proxy in benthic foraminifera: new calibrations from the Florida Straits and a hypothesis regarding $\mathrm{Mg} / \mathrm{Li}$. Paleoceanogr 23, PA2220.

CARINA Group, 2009. Carbon in the Atlantic Ocean Region - The CARINA Project: Results and Data. Version 1.0. Carbon Dioxide Information Analysis Center. Oak Ridge National Laboratory. U.S. Department of Energy. Oak Ridge, Tennessee. doi: 10.3334/CDIAC/otg.CARINA.ATL.V1.0. 〈http://cdiac.ornl.gov/ftp/oceans/CAR INA/CARINA_Database/CARINA.ATL.V1.0/>.

Case, D., Robinson, L.F., Auro, M.E., Gagnon, A.C., 2010. Environmental controls on $\mathrm{Mg}$ and Li in deep-sea scleractinian coral. Earth Planet. Sci. Lett. 300 (3-4), 215-225.

Chan, L.H., Drummond, D., Edmond, J.M., Grant, B., 1977. On the barium data from the Atlantic GEOSECS expedition. Deep-Sea Res. 24 (7), 613-649.

Cheng, H., Adkins, J.F., Edwards, R.L., Boyle, E.A., 2000a. U-Th dating of deep-sea corals. Geochim. Cosmochim. Acta 64, 2401-2416.

Cheng, H., Edwards, R.L., Hoff, J., Gallup, C.D., Richards, D.A., Asmerom, Y., 2000b. The half-lives of uranium-234 and thorium-230. Chem. Geol. 169, 17-33.

Coggon, R.M., Teagle, D.A., Smith-Duque, C.E., Alt, J.C., Cooper, M.J., 2010. Reconstructing past seawater $\mathrm{Mg} / \mathrm{Ca}$ and $\mathrm{Sr} / \mathrm{Ca}$ from mid-ocean ridge flank calcium carbonate veins. Science 327, 1114-1117, http://dx.doi.org/10.1126/science.1182252.

Colman, J.G., Gordon, D.M., Lane, A.P., Forde, M.J., Fitzpatrick, J., 2005. Carbonate mounds off Mauritania, Northwest Africa: status of deep-water corals and implications for management of fishing and oil exploration activities. In: Freiwald, J.M., Roberts, J.M. (Eds.), Cold-water Corals and Ecosystems. Springer, Heidelberg, pp. 417-441.

De Mol, B., Kozachenko, M., Wheeler, A., Alvares, H., Henriet, J.-P., Olu-Le Roy, K. 2007. Thérèse Mound: a case study of coral bank development in the Belgica Mound Province, Porcupine Seabight. Int. J. Earth Sci. 96, 103-120.

De Mol, B., Van Rensbergen, P., Pillen, S., Van Herreweghe, K., Van Rooji, D., McDonnell, A., Huvenne, V., Ivanov, M., Swennen, R., Henriet, J.P., 2002. Large deep-water coral banks in the Porcupine Basin, southwest of Ireland. Mar. Geol. 188, 193-231.

Dickson, R.R., McCave, I.N., 1986. Nepheloid layers on the continental slope west of Porcupine Bank. Deep-Sea Res. 33, 791-818.

Dorschel, B., Hebbeln, D., Rüggeberg, A., Dullo, W.-C., Freiwald, A., 2005. Growth and erosion of a cold-water coral covered carbonate mound in the Northeas Atlantic during Late Pleistocene and Holocene. Earth Planet. Sci. Lett. 233, $33-44$.

Dullo, W.-C., Flögel, S., Rüggeberg, A., 2008. Cold-water coral growth in relation to the hydrography of the Celtic and Nordic European continental margin. Mar. Ecol. Prog. Ser. 371, 165-176.

Dymond, J., Suess, E., Lyle, M., 1992. Barium in deep-sea sediment: a geochemical proxy for paleoproductivity. Paleoceanography 7, 163-181.

Eisele, M., Hebbeln, D., Wienberg, C., 2008. Growth history of a cold-water coral covered carbonate mound - Galway Mound, Porcupine Seabight, NE-Atlantic. Mar. Geol. 253, 160-169.

Eisele, M., Frank., N., Wienberg, C., Hebbeln, D., López Correa, M., Douville, E., Freiwald, A., 2011. Productivity controlled cold-water coral growth periods during the last glacial off Mauritania. Mar. Geol. 280 (1-4), 143-149.

Expedition 307 Scientists, 2006. Site U1317. In: Ferdelman, T.G., Kano, A., Williams, T., Henriet, J.-P., and the Expedition 307 Scientists. Proceedings of the Integrated Ocean Drilling Program, vol. 307. Integrated Ocean Drilling Program Management International, Inc. Washington, DC. doi:10.2204/iodp. proc.307.104.2006

Fantle, M.S., DePaolo, D.J., 2006. Sr isotopes and pore fluid chemistry in carbonate sediment of the Ontong Java Plateau: calcite recrystallization rates and evidence fo a rapid rise in seawater Mg over the last 10 million years. Geochim. Cosmochim. Acta 70, 3883-3904, http://dx.doi.org/10.1016/j.gca.2006.06.009.

Fietzke, J., Liebetrau, v., Eisenhauer, A., Dullo, W-Chr., 2005. Determination of uranium isotope ratios by multi-static MIC-ICP-MS: method and implementation for precise $U$ - and Th-series isotope measurements. JAAS 20, 395-401, http://dx.doi.org/10.1039/B415958F.

Fosså, J.H., Lindberg, B., Christensen, O., Lundälv, T., Svellingen, I., Mortensen, P.B. Alvsvåg, J., 2005. Mapping of Lophelia reefs in Norway: experiences and survey methods. In: Freiwald, A., Roberts, J.M. (Eds.), Cold-water Corals and Ecosystems. Springer, Berlin Heidelberg, pp. 359-391.

Foubert, A., Beck, T., Wheeler, A.J., Opderbecke, J., Grehan, A., Klages, M., Thiede, J., Henriet, J.-P., Polarstern ARK-XIX/3a Shipboard Party, 2005. New View of the Belgica Mounds, Porcupine, NE Atlantic: preliminary results from the Polarstern ARK-XIX/3a ROV cruise. In: Freiwald, A., Roberts, J.M. (Eds.), Cold-water Corals and Ecosystems. Springer, Berlin Heidelberg. pp. 403-415.

Foubert, A., Van Rooij, D., Blamart, D., Henriet, J.-P., 2007. X-ray imagery and physical core logging as a proxy of the content of sediment cores in cold-water coral mound provinces: a case study from Porcupine Seabight, SW of Ireland. Int. J. Earth Sci. 96, 141-158.

Foubert, A., Henriet, J.-P., 2009. Nature and significance of the Recent Carbonate Mound Record. Lecture Notes in Earth Sciences, vol. 126. Springer-Verlag Berlin p. 298

Frank, N., Lutringer, A., Paterne, M., Blamart, D., Henriet, J.-P., van Rooij, D., van Weering, T.C.E., 2005. Deep-water corals of the northeastern Atlantic margin: carbonate mound evolution and upper intermediate water ventilation during the Holocene. In: Freiwald, A., Roberts, J.M. (Eds.), Cold-water Corals and Ecosystems. Springer, Heidelberg, pp. 113-133.

Frank, N., Ricard, E., Lutringer-Paque, A., van der Land, C., Colin, C., Blamart, D. Foubert, A., Van Rooij, D., Henriet, J.-P., de Haas, H., van Weering, T.C.E, 2009.
The Holocene occurrence of cold-water corals in the NE Atlantic: implications for coral carbonate mound evolution. Mar. Geol. 266, 129-142.

Frank, N., Freiwald, A., López Correa, M.., Wienberg, C., Eisele, M., Hebbeln, D., Van Rooij, D., Henriet, J.P., Colin, C., van Weering, T., de Haas, H., Buhl-Mortensen, P. Roberts, J.M., De Mol, B., Douville, E., Blamart, D., Hatte, C., 2011. Northeastern Atlantic cold-water coral reefs and climate. Geology 39 (8), 743-746, http://dx. doi.org/10.1130/G31825.1

Freiwald, A., Fosså, J.H., Grehan, A., Koslow, T., Roberts, J.M., 2004. Cold-water coral reefs. UNEP-WCMC Biodiversity Series 22. UNEP-WCMC, Cambridge p. 84.

Freiwald, A., Beuck, L., Rüggeberg, A., Taviani, M., Hebbeln, D., 2009. The white coral community in the central Mediterranean Sea revealed by ROV surveys. Oceanography 22, 58-74.

Gradstein, F.M., Ogg, J.G., Smith, A.G., 2004. A Geological Time Scale. University Press, Cambridge p. 589.

Guinotte, J.M., Orr, J., Cairns, S., Freiwald, A., Morgan, L., George, R., 2006. Will human-induced changes in seawater chemistry alter the distribution of deepsea scleractinian corals? Front. Ecol. Environment 4 (3), 141-146.

Hathorne, E., James, R.H., 2006. Temperoal record of lithium in seawater: a tracer for silicate weathering? Earth Planet. Sci. Lett. 246, 393-406.

Hathorne, E., Felis, T., Suzuki, A., Kawahata, H., Gabioch, G., 2013. Lithium in the aragonite skeletons of massive Porites corals: a new tool to reconstruct tropical sea surface temperatures. Paleoceanography 28 (1), 143-152, http://dx.doi.org/ 10.1029/2012PA002311.

Henriet, J.P., Guidard, S., Team, O.P., 2002. Carbonate mounds as a possible example for microbial activity in geological processes. In: Wefer, G., et al. (Eds.), Ocean Margin Systems. Springer, Berlin, Heidelberg, pp. 439-455.

Huvenne, V.A.I., De Mol, B., Henriet, J.-P., 2003. A 3D seismic study of the morphology and spatial distribution of buried coral banks in the Porcupine Basin, SW of Ireland. Mar. Geol. 198 (5-25), http://dx.doi.org/10.1016/S00253227(03)00092-6.

Huvenne, V.A.I., Bailey, W.R., Shannon, P., Naeth, J., di Primio, R., Henriet, J.P., Horsfield, B., de Haas, H., Wheeler, A., Olu-Le Roy, K., 2007. The Magellan mound province in the Porcupine Basin. Int. J. Earth Sci. 96, 85-101.

Huvenne, V.A.I., Van Rooij, D., De Mol, B., Thierens, M., O'Donnell, R., Foubert, A. 2009. Sediment dynamics and palaeo-environmental context at key stages in the Challenger cold-water coral mound formation: clues from sediment deposits at the mound base. Deep Sea Res. I 56 (12), 2263-2280.

Huvenne, V.A.I., Tyler, P.A., Masson, D.G., Fisher, E.H., Hauton, C., Hühnerbach, V., Le Bas, T.P., Wolff, G.A., 2011. A picture on the wall: innovative mapping reveals cold-water coral refuge in submarine canyon. PLoS ONE 6 (12), e28755 http://dx.doi.org/10.1371/journal.pone.0028755.

Kano, A., Ferdelman, T.G., Williams, T., Henriet, J.-P., Ishikawa, T., Kawagoe, N. Takashima, C., Kakizaki, Y., Abe, K., Sakai, S., Browning, E.L., Li, X., 2007. Age constrains on the origin and growth history of a deep-water coral mound in the northeast Atlantic drilled during Integrated Ocean Drilling Program Expedition. Geology 35, 1051-1054.

Khélifi, N., Sarnthein, M., Andersen, N., Blanz, T., Frank, M., Garbe-Schönberg, D., Haley, B.A., Stumpf, R., Weinelt, M., 2009. A major and long-term Pliocene intensification of the Mediterranean Outflow (3.4-3.3). Geology 37 (9), 811-814.

Kiriakoulakis, K., Freiwald, A., Fischer, E., Wolff, G.A., 2007. Organic matter quality and supply to deep-water coral/mound systems of the NW European Continental Margin. Int. J. Earth Sci. 96, 159-170.

LaVigne, M., Hill, T.M., Spero, H.J., Guilderson, T.P., 2011. Bamboo coral Ba/Ca: Calibration of a new deep ocean refractory nutrient proxy. Earth Planet. Sci. Lett. 312, 506-515, http://dx.doi.org/10.1016/j.epsl.2011.10.013.

Lea, D.W., Shen, G.T., Boyle, E.A., 1989. Coralline barium records temporal variability in equatorial Pacific upwelling. Nature 340, 373-375.

Lea, D.W., Boyle, E.A., 1991. Barium in planktonic foraminifera. Geochim. Cosmochim. Acta 55, 3321-3331.

Lindberg, B., Berndt, C., Mienert, J., 2007. The Fugløy Reef at 70N; acoustic signature geologic, geomorphologic and oceanographic setting. Int. J. Earth Sci. 96, 201-213.

isiecki, L.E. Raymo, M.E., 2005. A Pliocene-Pleistocene stack of 57 globally distributed benthic $\delta^{18} \mathrm{O}$ records. Paloeceanography 20, PA1003, http://dx.doi. org/10.1029/2004PA001071.

Louwye, S., Foubert, A., Mertens, K., Van Rooij, D., IODP Expedition 307 Scientific Party, 2007. Integrated stratigraphy and palaeoecology of the Lower and Middle Miocene of the Porcupine Basin. Geol. Mag. 145, 1-24.

McArthur, J.M., Howarth, J., 2004. Strontium isotope stratigraphy. In: Smith, A.G. (Ed.), A Geological Time Scale. Cambridge University Press, pp. 96-105.

Mienis, F., Van Weering, T., De Haas, H., De Stigter, H., Huvenne, V., Wheeler, A. 2006. Carbonate mound development at the SW Rockall Trough margin based on high resolution TOBI and seismic recording. Mar. Geol. 233, 1-19.

Montagna, P., McCulloch, M., Taviani, M., Remia, A., Rouse, G., 2005. High-resolution trace and minor element compositions in deep-water scleractinian corals Desmophyllum Dianthus) from the Mediterranean Sea and the Great Australian Bight. In: Freiwald, A., Robersts, J.M. (Eds.), Cold-Water Corals and Ecosystems. Springer-Verlag, BerlinHeidelberg, pp. 1109-1126.

Montero-Serrano, J.-C., Frank, N., Tisnérat-Laborde, N., Colin, C., Wu, C.-C., Shen, C.-C. Copard, K., Orejas, C. Gori, A., De Mol, L, Van Rooij, D., Reverdin, G., Douville, E, 2013. Decadal changes in mid-depth water mass dynamics of the Northeastern Atlantic margin (Bay of Biscay). Earth Planet. Sci. Lett. 364, 134-144.

Mudelsee, M., Schulz, M., 1997. The Mid-Pleistocene climate transition: onset of 100 ka cycle lags ice volume build by 280 ka. Earth Planet. Sci. Lett. 151 (1-2), $117-123$. 
Naafs, B.D.A., Stein, R., Hefter, J., Khélifi, N., De Schepper, S., Haug, G.H., 2010. Late Pliocene changes in the North Atlantic Current. Earth Planet. Sci. Lett. 298, 434-442.

Nürnberg, D., Tiedemann, R., 2004. Environmental change in the Sea of Okhotsk during the last 1.1 million years. Paleoceanography 19, http://dx.doi.org/ 10.1029/2004PA001023.

Okai, T., Suzuki, A., Kawahata, H., Terashima, S., Imai, N., 2002. Preparation of a new Geological Survey of Japan geochemical reference material: coral JCp-1. Geostand. Newslett. 26, 95-99.

Okai, T., Suzuki, A., Terashima, S., Inoue, M., Nohara, M., Kawahata, H., Imai, N., 2004. Collaborative analysis of GSJ/AIST geochemical reference materials JCp-1 (Coral) and JCt-(Giant Clam). Chikyukagaku (Geochemistry) 38, 281-286.

Purser, A., Larsson, A.I., Thomsen, L., Van Oevelen, D., 2010. The influence of flow velocity and food concentrations on Lophelia pertusa (Scleractinian) zooplankton capture rates. J. Exp. Mar. Biol. 395, 55-62.

Raddatz, J., Rüggeberg, A., Margreth, S., Dullo, W.Chr., the IODP Expedition 307 Scientific Party, 2011. Paleoenvironmental reconstruction of Challenger Mound initiation in the Porcupine Seabight, NE Atlantic. Mar. Geol. 282 (79-90), http: //dx.doi.org/10.1016/j.margeo.2010.10.019.

Roberts, J.M., Wheeler, A.J., Freiwald, A., 2006. Reefs of the deep: the biology and geology of cold-water coral ecosystems. Science 312, 543-547.

Robinson, L.F., Belshaw, N.S., Henderson, G.M., 2004. U and Th concentrations and isotope ratios in modern carbonates and waters from the Bahamas. Geochim. Cosmochim. Acta 98 (8), 1777-1789.

Rosenthal, Y., Field, M.P., Sherrell, R.M., 1999. Precise determination of element/ calcium ratios in calcareous samples using sector field inductively coupled plasma mass spectrometry. Anal. Chem. 71 (15), 3248-3253.

Rüggeberg, A., Dorschel, B., Dullo, C., Hebbeln, D., 2005. Sedimentary patterns in the vicinity of a carbonate mound in the Hovland Mound Province, northern Porcupine Seabight. In: Freiwald, A., Roberts, J.M. (Eds.), Cold-water Corals and Ecosystems. Springer Verlag, Berlin Heidelberg, pp. 87-112.

Rüggeberg, A., Dullo, C., Dorschel, B., Hebbeln, D., 2007. Environmental changes and growth history of a cold-water carbonate mound (Propeller Mound, Porcupine Seabight). Int. J. Earth Sci. 96, 57-72.

Rüggeberg A. Fietzke, J, Liebetrau, V Fisenhauer, A, Dullo, W-C, Freiwald, A 2008. Stable strontium isotopes $\left(\delta^{88 / 86} \mathrm{Sr}\right)$ in cold-water corals - a new proxy for reconstruction of intermediate ocean water temperatures. Earth Planet. Sci. Lett. 269, 570-575.

Sakai, S., Kano, A., Abe, K., 2009. Origin, glacial-interglacial responses, and controlling factors of a cold-water coral mound in NE Atlantic. Paleoceanography 24, PA2213, http://dx.doi.org/10.1029/2008PA001695.

Schlitzer, R., 2012. Ocean Data View. 〈http://odv.awi.de〉.

Schönfeld, J., Zahn, R., 2000. Late glacial to holocene history of the Mediterranean Outflow. Evidence from benthic foraminiferal assemblages and stable isotopes at the Portuguese Margin. Palaeogeogr. Palaeoclimatol. Palaeoecol. 159, 85-111.

Schröder-Ritzrau, A., Freiwald, A., Mangini, A., 2005. U/Th-dating of deep-water corals from the eastern North Atlantic and the western Mediterranean Sea. In: Freiwald, J.M., Roberts, J.M. (Eds.), Cold-water Corals and Ecosystems. Springer, Heidelberg, pp. 691-700.

Shen, G.T., Boyle, E.A., 1988. Determination of lead, cadmium and other trace metals in annually-banded corals. Chem. Geol. 67, 47-62.

Stein, R., Hefter, J., Grützner, J., Voelker, A., Naafs, B.D.A., 2009. Variability of surfacewater characteristics and Heinrich-like events in the Pleistocene midlatitude North Atlantic Ocean: biomarker and XRD records from IODP Site U1313 (MIS 16-9). Paleoceanography 24, PA2203 2210.1029/2008PA001639.
Stirling, C.H., Esat, T.M., Lambeck, K., McCulloch, M.T., 1998. Timing and duration of the Last Interglacial: evidence for a restricted interval of widespread coral reef growth. Earth Planet. Sci. Lett. 160, 745-762.

Thierens, M., Titschack, J., Dorschel, B., Huvenne, V.A.I., Wheeler, A.J., Stuut, J.-B., O'Donnel, R., 2010. The 2.6 Ma depositional sequence from the Challenger coldwater coral carbonate mound (IODP Exp. 307): sediments contributors and hydrodynamic paleo-environments. Mar. Geol. 271, 260-277.

Thierens, M., Pirlet, H., Colin, C., Latruwe, K., Vanhaecke, F., Lee, J.R., Stuut, J.-B., Titschack, J., Huvenne, V.A.I., Dorschel, B., Wheeler, A.J., Henriet, J.-P., 2012. Icerafting from the British-Irish ice sheet since the earliest Pleistocene (2.6 million years ago): implications for long-term mid-latitude ice-sheet growth in the North Atlantic region. Quaternary Sci. Rev. 44, 229-240.

Thompson, W.G., Spiegelman, M.W., Goldstein, S.L., Speed, R.C., 2003. An opensystem model for U-series age determinations of fossil corals. Earth Planet. Sci. Lett. 210, 365-381.

Titschack, J., Thierens, M., Dorschel, B., Schulbert, C., Freiwald, A., Kano, A., Takashima, C., Kawagoe, C., Li, N., IODP, X., Expedition 307 Scientific Party, 2009. Carbonate budget of a cold-water coral mound (Challenger Mound, IODP Exp. 307). Mar. Geol. 259 (1-4), 36-46.

Van Rooij, D., Blamart, D., Richter, T., Wheeler, A., Kozachenko, M., Henriet, J.P., 2007. Quaternary sediment dynamics in the Belgica mound province, Porcupine Seabight: ice-rafting events and contour current processes. Int. J. Earth Sci. 96 (1), 121-140.

Van Weering, C.E., de Haas, H., de Stigter, H., Lykke-Anderson, H., Kouvaev, I., 2003. Structure and development of giant carbonate mounds at the SW and SE Rockall Trough margins, NE Atlantic Ocean. Mar. Geol. 198, 67-81.

Wheeler, A., Beyer, A., Freiwald, A., de Haas, H., 2007. Morphology and environment of cold-water coral carbonate mounds on the NW European margin. Int. J. Earth Sci. 96 (1), 37-56.

Wheeler, A., Kozachenko, M., Henry, L.-A., Foubert, A., de Haas, H., Huvenne, V.A.I., Masson, D.G., Olu, K., 2011. The Moira Mounds, small cold-water coral banks in the Porcupine Seabight, NE Atlantic: Part A-an early stage growth phase for future coral carbonate mounds?. Mar. Geol., 282; , pp. 53-64.

White, M., Mohn, C., de Stigter, H., Mottran, G., 2005. Deep-water coral development as a function of hydrodynamics and surface productivity around the submarine banks of the Rockall Trough, NE Atlantic. In: Freiwald, A., Roberts, J. M. (Eds.), Cold-Water Corals and Ecosystems. Springer, Berlin, pp. 503-514.

White, M., 2007. Benthic dynamics at the carbonate mound regions of the Porcupine Sea Bight continental margin. Int. J. Earth Sci. 96, 1-9.

White, M., Dorschel, B., 2010. The importance of the permanent thermocline to the cold-water coral mound distribution in the North Atlantic. Earth Planet. Sci. Lett. 296, 395-402.

Wienberg, C., Hebbeln, D., Fink, H.G., Mienis, F., Dorschel, B., Vertino, A., López Correa, M., Freiwald, A., 2009. Scleractinian cold-water corals in the Gulf of Cádiz - first clues about their spatial and temporal distribution. Deep Sea Res. I $56,1873-1893$.

Wienberg, C., Frank, N., Mertens, N.K., Stuut, J.-B., Marchant, M., Fietzke, J., Mienis, F. Hebbeln, D., 2011. Glacial cold-water coral growth in the Gulf of Cádiz: implications of increased palaeo-productivity. Earth Planet. Sci. Lett. 298, 405-416.

Williams, T., Kano, A., Ferdelman, T., Henriet, J.-P., Abe, K., Andres, M.S., Bjerager, M., Browning, E.L., Cragg B.A., De Mol, B., Dorschel, B., Foubert, A., Frank, T.D., Fuwa, Y., Gaillot, P., Gharib, J., Gregg, J.M., Huvenne, V.A.I., Léonide, P., Mangelsdorf, K., Tanaka, A., Monteys, X., Novosel, I., Sakai, S., Samarkin, V.A., Sasaki, K., Spivack, A.J., Takashima, C., Titschack, J., 2006. Cold-water coral mounds revealed. EOS Trans. AGU 87, 525-526. 